\title{
Geotechnical Investigation for the Groundwater Damage Analysis of the Shahe Ancient Bridge Site in Xi'an, China
}

\section{Jing Cao ( $\boldsymbol{\nabla}$ jingcao@snnu.edu.cn )}

Shaanxi Normal University https://orcid.org/0000-0001-8249-2915

\section{Bingjie Mai}

Shaanxi Normal University

\section{Hua Chen}

JinZhou Preservation Center of Cultural Relics

Yuhu Li

Shaanxi Normal University

Juanli Wang

Shaanxi normal university

\section{Research article}

Keywords: geotechnical investigation, groundwater, damage analysis, cultural ruins

Posted Date: January 9th, 2021

DOI: https://doi.org/10.21203/rs.3.rs-141276/v1

License: @ (i) This work is licensed under a Creative Commons Attribution 4.0 International License. Read Full License 


\section{Abstract}

In terms of cultural ruins, the earthen ruins and its subsurface environment were acted either as a carrier or supports above ground cultural heritage, the groundwater was found to be the greatest factor that affected and accelerated destruction of the ruins without any doubt. This paper presents an approach that achieved geochemical data and hydrological processes occurring of the ruins and surrounding area by the data analysis of geotechnical investigation, it is found that the fluctuations in groundwater level affected the movement of water and salt, thereby influenced and accelerate the deterioration, and also caused microbes, creatures, and plants to erode the ruins. The stratigraphy revealed good correlation with the status of the ruins, the scientific analysis of the samples, the damage mechanism. These monitoring data will be used to discuss and predict the effects of various types of damage factors on long term preservation and proposed feasible for longer countermeasures in preservation studies. This paper takes the Xianyang Shahe Ancient Bridge site as the research object, to be precise, it takes the wooden structure site as the research object, through the methods of geotechnical survey and site sample analysis, the relationship between the environment of the site and the cause of disease is explored.

\section{Introduction}

Cultural Heritage were defined as the set of the large settlements, city sites, palaces, tombs, tombs and other sites and sites of great scale, with great value, cultural and artistic significance and far-reaching influence, which were usually subjected to the natural and anthropogenic factors ${ }^{[1-2]}$.

In terms of cultural monuments, the earthen ruins and its subsurface environment act either as a carrier or supports above ground cultural heritage. Among numerous factors that affect and accelerate destruction, the groundwater ${ }^{[3,14-15]}$, as the greatest expenditure, exerta considerable damage effect without any doubt, for the earthen ruins or the above-ground monuments. The fluctuations in groundwater level affected the movement of water and salt, thereby influenced ruins salinization levels and accelerate the development of the deterioration for the earthen ruins and also the cultural relics of above-ground. Almost certainly, it is not enough to protect the above-ground ruins itself ${ }^{[4-7]}$.

Until the last decade, cultural heritage preservation studies were changed to conducted by a more multidisciplinary and holistic approach ${ }^{[7-10]}$, where earth scientists, chemists, geotechnicians and hydrogeologists, were incorporated in preservation studies, and pay more attention to the wider environmental situation. Protocols for the causes of disease assessment methods for the cultural heritage preservation, particularly ruins affected by the groundwater damage effect have still not been standardized. Accordingly, huge attention is directed towards the development of innovative and reliable approaches for its damage analysis of the cultural ruins, by the multidisciplinary collaboration contributes ${ }^{[11-13]}$ to a better understanding of preservation conditions where groundwater and cultural heritage are interdependent.

This paper presents an approach that achieved geochemical datas and hydrological processes occurring of the ruins and surrounding area and analysed its cause from geological survey. Secondly, these monitoring data will be used to predict the effects of various types of perturbation on long term preservation potential and proposed feasible and applicable for longer countermeasures in preservation studies. 
The Xianyang Shahe Ancient Bridge Site is located in the Shahe Ancient River Channel, 10 kilometers southwest of Xianyang City, Shaanxi Province (as shown in Figure 1). The Shaanxi Provincial Archaeological Institute excavated it in 1986 and cleaned up two bridge sites ${ }^{[14]}$ : the piles of the No. 1 bridge were neatly arranged, and 16 rows of 143 bridge piles were cleared; the No. 2 bridge site was cleared of 5 rows of 40 bridge piles, in east-west arrangement, north-south correspondence; the bridge width is about 16 meters. According to the expert's argument ${ }^{[15]}$, from the geographical point of view, the bridge is the first bridge out of the Chang'an City in the west. It is the necessary bridge for Qin Xianyang City, Han Chang'an City to Shanglin Garden, and west to Bashu to cross the Feng River. It is the earliest wooden bridge site discovered in China so far. In 1989, it was rated as the top ten archaeological discoveries in the country. It was announced as a key cultural relics protection unit of Shaanxi Province in 1992; it was announced as the seventh batch of national key cultural relics protection units by the State Council in 2013. The bridge is the "Desert Silk Road" connecting the northwest and the "Southwest Silk Road" connecting the southwest, so it is also called "the First Bridge of the Wanli Silk Road", which has important academic value for the archaeology of the Silk Road; at the same time, the ancient wooden bridge of such a span and scale is really rare. It provides the valuable information and evidence for the archeological and academic research on the history of transportation and bridge history in China. It is the true preservation of the ancient bridge construction technology and large-scale transportation construction in the territory at that time.

The Xianyang Shahe Ancient Bridge Site No. 1 was excavated with the length of 106 meters and the width of 16 meters, et a temporary protection shed was built on the site. The bridge piles were built with the 16 rows of 112 logs, each row with spacing of 3 to 5 meters (as shown in Figure 2). According to C14 measurement, the site was built in the Qin Dynasty 2120 years ago. The preservation status is worrying: after the excavation of the No. 1 site pit bridge pile, the wooden pile body has various degrees of decay, cracking, surface pollution, mold, crooked flash, breakage and other diseases, which has seriously affected its display and long-term preservation. And the degree of disease is increasing year by year, and the site has the urgent need for protection and restoration. In particular, for the Xianyang Shahe ancient bridge ruins as described in this article, the wooden bridge piles on the leakage part of the surface of the ruins are important cultural relics that are inseparable and cannot be separated from the existence of the ruins, and are an integral part of the overall bridge structure.

Chinese ancient sites have a wide distribution, many types and large scales, and they are closely related to the surrounding environment. The differences in the types and materials of the sites themselves, as well as the variable and complex relationship of geological, hydrological and environmental factors, make it extremely difficult to protect the sites. With the improvement of requirements and concepts for the protection of large sites, the protection of the sites not only involves multidisciplinary applications such as architecture, archaeology, geology, physics, biology, etc., it also requires diagnosis from the root cause and explanation of the cause and destruction mechanism that caused the diseases of the sites, and more importantly, how to mitigate or effectively curb the development of its destruction with minimal intervention, and establish a set of scientific diagnosis, treatment, and effective management of the protection idea of the large sites. Consequently, for the protection of ancient sites, we shall fundamentally seek a breakthrough in the correlation between the environment and the cause of diseases. 
There have been many reports on wooden structure sites, but they mainly focus on several aspects of disease diagnosis and preservation status evaluation, and the protection of such sites is mostly based on the classification and protection thinking of distinguishing the types of soil and cultural relics of the sites: generally, the soil of the sites is mainly reinforced to prevent weathering, while the remains of wooden cultural relics mainly focus on anti-corrosion and reinforcement protection, and research on the suitability of the preservation environment. It is not difficult to see that the integrity of the wooden structure sites has been divided into two research objects, the earthen site and the wooden cultural relic, ignoring the closely connected and indivisible integrity of the two. It can be seen that there is still a certain degree of blindness in the protection of wooden structure sites, and there is a lack of universal and systematic protection ideas. This paper takes the Xianyang Shahe Ancient Bridge site as the research object, to be precise, it takes the wooden structure site as the research object, through the methods of geotechnical survey and site sample analysis, the relationship between the environment of the site and the cause of disease is explored.

\section{Experimental Methods}

\subsection{Geotechnical investigation site method}

After fully collecting and using the preliminary data and regional data, combined with the characteristics of No. 1 bridge site of the Xianyang Shahe Ancient Bridge, it mainly uses the drilling method, including the comprehensive survey method of the engineering geological survey and mapping, in-situ testing, sample collection, indoor test survey and other exploration combining the test methods.

\subsection{Engineering geological mapping method}

The purpose is to investigate and study the topography, stratum lithology, geological structure, groundwater and surface water, and undesirable geological phenomena of the site, as well as the necessary surveying and mapping work, to provide the basis for evaluating the site's engineering geological conditions and rationally determining exploration work of the site. In this survey, the 1: 100 scale was used to conduct the research, analysis and detailed investigation on the area and surroundings, stratum, geological structure, and unfavorable geological effects of the Shahe Ancient Bridge site. The total station instrument was used to measure and locate the site.

\subsection{Drilling and shaft prospecting method}

It can take soil samples and in-situ test exploration holes along the Shahe Ancient Bridge site within at least $1 / 2$ of the total number of exploration holes, sample holes at least $1 / 3$, and arrange a certain number of controlled holes. According to the above principles, 8 exploration points (8 drill holes) are arranged in a grid according to the perimeter and corner points of the greenhouse, with the spacing of 24.57-34.73m; the depth of the exploration points is $15-20.5 \mathrm{~m}$. It is used to analyze the geotechnical structure and characteristics of the area where the Shahe Ancient Bridge site is located. The number of effective mechanical parameters satisfying the coefficient of variation of the main engineering geological layer within the survey depth is not less than 8 groups; the survey and measurement of exploration points adopts GPS survey and control according to the control points on the topographic map of the greenhouse area. After the exploration, the coordinates and elevation of all exploration points are re-measured. The coordinate system is the National 
Geodetic 2000 coordinate system, the $108^{\circ}$ central meridian, and the elevation adopts the National Geodetic 2000 elevation.

The control points used for measurement are as follows:

GPS01هX=3792502.4870, Y=562856.18, Z=349.245

GPS02 $₫ X=3792528.3774, Y=562761.8212, Z=348.0910$

\subsection{Sampling and testing method}

This method should be based on the principle of minimum intervention. The mud wall is used for drilling below the sampling water level, and the thin-walled earth borrower is used for static pressure over the water level. The original sample below the water level is taken from the drilling tool, and the quality class is the class I-II. (As shown in the figure 3) it can complete the standard penetration test in situ on site and heavy-duty dynamic penetration test on site, as well as routine tests of soil samples, collapsibility test, self-weight collapsibility test, consolidation fast shear test, compression test, and penetration test, soil and water corrosion analysis, rock compressive strength analysis test, etc.

\subsection{Geotechnical and mechanical parameters statistics and values}

The physical and mechanical properties of each layer are counted according to the layer of rock and soil, and the obvious discrete data caused by the unevenness or interlayer was removed. The recommended values of the general physical and mechanical parameters of the soil are statistical average values; the shear strength indicators (c, $\varphi$ values) are based on the standard values obtained from the statistics; the cone tip resistance $q_{c}$, the side friction resistance $f_{s}$, the shear wave velocity $V_{s}$ and the compression wave velocity $V_{p}$ and other in-situ test parameters give the recommended values based on the statistical average value of the test results; for the geotechnical parameters such as the bearing capacity characteristic value $d$, the standard value of the ultimate frictional resistance $\mathrm{q}_{\mathrm{sik}}$ of the surrounding soil of the bored pile and the standard value of the ultimate resistance $\mathrm{q}_{\mathrm{pk}}$, the various methods are combined to determine the recommended value.

\subsection{Identification of Wood Species}

As the wood samples taken at the site of the ruins all have different degrees of decay, it is necessary to saw after reinforcement treatment to take three-section standard cuboid samples (cross section, diameter section and chord section), soften and cut to obtain observation sections, so we can observe the structural characteristics of the wood through an optical microscope, then refer to the wood database Inside Wood, "Chinese Wood History" and wood atlas to identify wood species.

\subsection{Microbiological Testing}

In each site, left and right samples were collected from one randomly sampled, three biological replicates were made for left or right sites for subsequently sequencing amplicons. All sampled tissues were put into sterilized plastic bags. The regular CTAB method was taken to extract total DNA from Soil and bricks. The concentrations and purity of the isolated DNA were measured using NanoDrop ND-1000 spectrophotometer 
(Thermo Fisher Scientific, USA). A pair of primers of ITS3F (GCATCGATGAAGAACGCAGC) and ITS4R (TCCTCCGCTTATTGATATGC) were used to amplify fungal ITS2 region of rDNA. A pair of primers of 338F (ACTCCTACGGGAGGCAGCA) and 806R (GGACTACHVGGGTWTCTAAT) was applied for amplifying V3-V4 region of bacterial 16S rDNA. The PCR products were purified and sequenced with Illumina HiSeq. platform at Beijing Biomarker Biotechnology Co. LTD. (Hiseq 2500 PE250). All sequences data were deposited with PRJNA604508 ID at the Sequence Read Archive (SRA) of NCBI Database.

\subsection{Microstructure Characterization}

Through the Hyperdepth three-dimensional video microscope, scanning electron microscope observed the microscopic morphology and fiber structure characteristics of the wood, and obtained the characteristic performance indexes of the wood corresponding to the sampling sites at different burial depths.

\section{Results And Discussion}

Through the investigation and research on the topography, stratum lithology, geological structure, groundwater and surface water, and unfavorable geological phenomena of the site, it is found that: the fluctuations in groundwater level affected the movement of water and salt, thereby influenced and accelerate the deterioration, and also caused microbes, creatures, and plants to erode the ruins. The stratigraphy revealed good correlation with the status of the ruins, the scientific analysis of the samples, the damage mechanism.

\subsection{Terrain and topography}

The Shahe Ancient Bridge is located on the south bank of the Weihe River in Xianyang City. The ground elevation is between $389.76 \mathrm{~m}$ and $390.23 \mathrm{~m}$, and the site is relatively flat. The geomorphic unit belongs to the first-level terrace of the right bank of the Weihe River. The Weihe Plain area is formed by the alluvial deposits of the Weihe River and is divided into four small geomorphic units, namely the Weihe floodplain, first-level terrace, second-level terrace, and third-level terrace. The first-level terrace is $0.5 \mathrm{~m}$ higher than the river bed, and it is an alluvial deposit formed in the Holocene. It is mainly composed of gravel and pebble. The first-level terrace is $380-400 \mathrm{~m}$ above sea level and is the stacked terrace. The upper part is sandy clay and the lower part is gravel and pebble layer.

\subsection{Meteorology and Hydrology}

The area where the Shahe Ancient Bridge site is located belongs to a warm temperate semi-humid continental monsoon climate area, with distinct cold, warm, dry and wet seasons, rich in light, heat and water resources. The area where it is located belongs to the Weihe River system of the Yellow River Basin and is located in the hydrogeological area of the river terrace. The Weihe River is the largest surface water system in the area. It flows from west to east along the southern edge of the municipal area. The water volume changes seasonally, with an average flow of $173 \mathrm{~m}^{3} / \mathrm{s}$. The river bed is wide and shallow, with the water depth of $3.0 \mathrm{~m}$ in the flat water period, and the river bed ratio drops by about $1 \%$; while the Feng River is a first-order tributary, and flows into the Weihe River from south to north, the river bed width is $80-250 \mathrm{~m}$, the river bed ratio drops by about $8.2 \%$, and the average flow rate is $9.41 \mathrm{~m}^{3} / \mathrm{s}$. 
The groundwater in the area where the Shahe Ancient Bridge site is located is mainly quaternary loose layer pore diving water and confined water: the diving water is mainly found in the Quaternary Upper Pleistocene and Middle Pleistocene alluvial sand soil, it is mainly supplied by atmospheric precipitation infiltration, irrigation and lateral runoff; the runoff direction is consistent with the terrain slope, flowing from southeast to northwest, and vertical quaternary loose layer pore water and shallow confined water are connected and supplied through overflow. The drainage methods are mainly evaporation, lateral runoff drainage, artificial mining, and overflow drainage of diving. The unit water inflow is $5-10 \mathrm{~m}^{3} / \mathrm{h} * \mathrm{~m}$, and the aquifer thickness is 34 $46 \mathrm{~m}$. It is recharged by runoff from upstream rivers and runoff from the confined aquifer of the Loess Plateau, the confined aquifer is lacustrine sediments, and the lithology is mainly medium coarse sand and gravel; the thickness of the aquifer is $27-80 \mathrm{~m}$, and the unit water inflow is $1-10 \mathrm{~m}^{3} / \mathrm{h} * \mathrm{~m}$; the salinity is less than $230 \mathrm{mg} / \mathrm{L}$, which is fresh water; the terrace where the site survey area is located belongs to the strong water-rich areastrong water-rich area, and the water inflow is $₫ 2500-5000 \mathrm{~m}^{3} / \mathrm{d}$.

In the survey: it is found that the natural precipitation in the site area varies greatly from year to year, and the seasonal distribution is uneven; the groundwater level is closely related to the season, climate, groundwater storage, recharge and discharge. In summer, there is abundant precipitation and the water level rises significantly; in winter, precipitation decreases and the groundwater level drops accordingly. The underground diving level has an elevation of $343.00-344.40 \mathrm{~m}$ and a water level of $5.20-5.80 \mathrm{~m}$. Although the upper layer of fine sand may have water stagnant in the upper layer, generally no engineering precipitation is required.

\subsection{Geotechnical characteristics}

The strata within the depth of exploration is described in detail as follows:

Following the geological stratigraphy observed in borehole, the figure 4 shows that the stratum where the site is located is mainly composed of Quaternary alluvial fine sand, coarse sand, gravel sand, boulder and silty clay.

(1) Pleistocene Q3 on the fourth system

هFine sand Q3al: layer thickness 1.0-4.0m, buried depth 1.0-7.0m, bottom elevation 342.20-348.60m. $\triangle$ Medium sand Q3al: layer thickness 4.00-9.60m, buried depth 7.20-18.1m, layer bottom elevation 331.20-341.50m. هGravel Q3al: layer thickness $2.00-3.10 \mathrm{~m}$, buried depth $10.30-12.20 \mathrm{~m}$, layer bottom elevation 336.60338.40m. 区Boulder Q3al: layer thickness $2.00-7.80 \mathrm{~m}$, buried depth $14.00-20.00 \mathrm{~m}$, layer bottom elevation $328.80-335.60 \mathrm{~m}$. The overall distribution of the stratum is stable, the sedimentation rhythm is clear, the uniformity of the foundation soil of each layer is good, the bearing capacity is gradually increased from top to bottom, and the geotechnical engineering properties are gradually improved from shallow to deep. The compressibility of the formation is relatively good, and the strength is relatively high. The whole field is basically stable-stable foundation. The foundation soil of shallow foundation is mainly Quaternary Upper

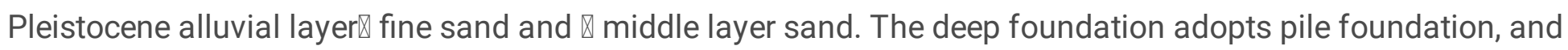
the stratum beside the pile is composed of fine sand, coarse sand, gravel sand, round gravel and silty clay. The pile-end stratum is dominated by silty clay and sand, and the silty clay layer is discontinuous. It is recommended to use $\mathbb{\nabla}$ layer of fine sand as the supporting layer. 


\subsection{Permeability}

Tab. 1. List of indoor penetration test results

\begin{tabular}{|c|c|c|c|c|c|c|}
\hline $\begin{array}{l}\text { Statistics items } \\
\text { Test items }\end{array}$ & Unit & $\begin{array}{l}\text { Layer } \\
\text { number }\end{array}$ & $\begin{array}{l}\text { Maximum } \\
\text { value }\end{array}$ & $\begin{array}{l}\text { Minimum } \\
\text { value }\end{array}$ & $\begin{array}{l}\text { Average } \\
\text { value }\end{array}$ & Evaluation \\
\hline \multirow[t]{5}{*}{ 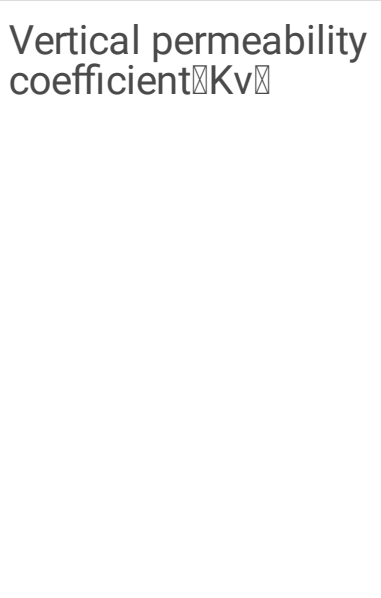 } & \multirow[t]{5}{*}{$\mathrm{cm} / \mathrm{s}$} & प & $5.44 \times 10^{-3}$ & $2.36 \times 10^{-3}$ & $3.67 \times 10^{-3}$ & $\begin{array}{l}\text { Medium } \\
\text { permeable }\end{array}$ \\
\hline & & प & $5.77 \times 10^{-2}$ & $5.31 \times 10^{-3}$ & $1.31 \times 10^{-2}$ & $\begin{array}{l}\text { Strongly } \\
\text { permeable }\end{array}$ \\
\hline & & प & $1.73 \times 10^{-1}$ & $7.82 \times 10^{-3}$ & $8.98 \times 10^{-2}$ & $\begin{array}{l}\text { Strongly } \\
\text { permeable }\end{array}$ \\
\hline & & Q & $6.76 \times 10^{-1}$ & $9.84 \times 10^{-2}$ & $3.66 \times 10^{-1}$ & $\begin{array}{l}\text { Strongly } \\
\text { permeable }\end{array}$ \\
\hline & & प & $3.48 \times 10^{-1}$ & $1.34 \times 10^{-5}$ & $1.16 \times 10^{-1}$ & $\begin{array}{l}\text { Strongly } \\
\text { permeable }\end{array}$ \\
\hline
\end{tabular}

In this investigation, the conventional physical and mechanical properties tests are conducted on the loesslike soil, ancient soil layer, silty clay and other soil samples. The layered statistics of the physical and mechanical properties of each soil layer; A standard penetration test was conducted to evaluate the permeability of each layer of sandy soil and cohesive soil distributed in the site. The statistical results of laboratory penetration test and particle analysis are shown in the following table. According to the permeability test results, it is found that the submersible water level of the site is $343.00-344.40 \mathrm{~m}$, and the buried water level is $5.20-5.80 \mathrm{~m}$. The groundwater is quaternary pore water, and the aquifer is the sand layer of the upper Pleistocene of the quaternary system with strong permeability.

\subsection{Environmental water and soil corrosion et evaluation}

As shown in the above Table 2, under long-term immersion conditions or alternating wet and dry conditions, the $\mathrm{pH}$ of the site's environmental water is $7.16-7.19$, and the $\mathrm{Cl}^{-}$content is $20.9 \mathrm{mg} / \mathrm{L}$, and the total mineralization is $557.82-575.6 \mathrm{mg} / \mathrm{L}$. The environmental water in the site area is slightly corrosive. The $\mathrm{pH}$ of the soil samples at the site is 8.67 , and the $\mathrm{Cl}^{-}$content is $40.2-43.6 \mathrm{mg} / \mathrm{kg}$, the total soluble salt is 499.1 $1128.8 \mathrm{mg} / \mathrm{kg}$, and the soil samples in the site are slightly corrosive.

\section{Tab. 2. List of groundwater corrosion evaluation}




\begin{tabular}{|c|c|c|c|c|c|c|}
\hline Aquifer & $\begin{array}{l}\text { Corrosion } \\
\text { evaluation }\end{array}$ & $\begin{array}{l}\text { Environment } \\
\text { type }\end{array}$ & Corrosive medium & Content & $\begin{array}{l}\text { Limit } \\
\text { value }\end{array}$ & $\begin{array}{l}\text { Corrosion } \\
\text { level }\end{array}$ \\
\hline \multirow{10}{*}{$\begin{array}{l}\text { Pore diving } \\
\text { Groundwater } \\
\text { depth 5.20区 } \\
5.80 \mathrm{~m}\end{array}$} & \multirow{5}{*}{$\begin{array}{l}\text { Corrosion of } \\
\text { water to } \\
\text { concrete } \\
\text { structure } \\
\text { according to } \\
\text { environmental } \\
\text { type }\end{array}$} & \multirow[t]{5}{*}{ प } & $\begin{array}{l}\text { Sulfate contentSO }{ }_{4}{ }^{2-} \\
(\mathrm{mg} / \mathrm{L})\end{array}$ & $\begin{array}{l}153.6 \mathrm{X} \\
165.1\end{array}$ & $\varangle 300$ & Micro \\
\hline & & & $\begin{array}{l}\text { Magnesium } \\
\text { contentMg }{ }^{2+}(\mathrm{mg} / \mathrm{L})\end{array}$ & $\begin{array}{l}23.3 \rrbracket \\
27.7\end{array}$ & $\varangle 2000$ & Micro \\
\hline & & & $\begin{array}{l}\text { Ammonium } \\
\text { contentNH }{ }_{4}^{+}(\mathrm{mg} / \mathrm{L})\end{array}$ & 0.2 & $\bigotimes 500$ & Micro \\
\hline & & & $\begin{array}{l}\text { Caustic content } \mathrm{OH}^{-} \\
(\mathrm{mg} / \mathrm{L})\end{array}$ & 0.0 & $\begin{array}{l}0 \\
43000\end{array}$ & Micro \\
\hline & & & Total salinity (mg/L) & $\begin{array}{l}557.82 \rrbracket \\
575.6\end{array}$ & 20000 & Micro \\
\hline & \multirow{3}{*}{$\begin{array}{l}\text { Corrosion of } \\
\text { concrete } \\
\text { structure by } \\
\text { permeable } \\
\text { water }\end{array}$} & \multirow[t]{3}{*}{ A } & $\mathrm{PH}$ value & $\begin{array}{l}7.16 \rrbracket \\
7.19\end{array}$ & $\varangle 6.5$ & Micro \\
\hline & & & AggressiveCO $_{2}(\mathrm{mg} / \mathrm{L})$ & 0.0 & Q15 & Micro \\
\hline & & & $\mathrm{HCO}_{3}^{-}(\mathrm{mmol} / \mathrm{L})$ & $\begin{array}{l}3.75 \square \\
3.80\end{array}$ & $\$ 1.0$ & Micro \\
\hline & \multirow{2}{*}{$\begin{array}{l}\text { Corrosion to } \\
\text { reinforcement } \\
\text { in reinforced } \\
\text { concrete } \\
\text { structures }\end{array}$} & $\begin{array}{l}\text { Long-term } \\
\text { immersion }\end{array}$ & \multirow[t]{2}{*}{$\mathrm{Cl}^{\prime}$ content $(\mathrm{mg} / \mathrm{L})$} & \multirow[t]{2}{*}{$\begin{array}{l}20.98 \\
20.9\end{array}$} & 10000 & Micro \\
\hline & & $\begin{array}{l}\text { Wet and dry } \\
\text { alternation }\end{array}$ & & & $\begin{array}{l}100 \rrbracket \\
500\end{array}$ & Micro \\
\hline
\end{tabular}

It is comprehensively inferred that the water level rises significantly during summer precipitation, but due to the protection of the greenhouse from the surface water in the area of the site, the evaporation is greater than the recharge. With the process of groundwater evaporation produced a significant phenomenon of soluble salt migration, especially for the geological environment of sandy soil layer in the site, on the one hand, the good permeability of the site soil enhanced the evaporation rate of groundwater and accelerated the speed of salt migration. More importantly, compared with the site soil, the capillary tubes of wooden bridge piles are better water transport channels, the truth is, choosing a more convenient channel is anyone would make, that was for the above reasons that the current preservation status of wooden bridge piles just verifies this inference.

\section{Preservation State Of The Ancient Wooden Bridge Piles}

However, the wooden bridge piles were buried in the sand for nearly two thousand years, after the excavation, nearly $1 / 3$ of the wooden bridge piles were exposed to the air as shown in the figure 2 . The ruin was damaged by natural factors after excavation, and the temporary protection shed conditions were limited, therefore, the overall preservation condition of the site was poor: the main diseases of the exposed wooden bridge piles on the ground were: decay, cracks, incompleteness, microbial damage, crooked flash, fracture, and discoloration, pollution, man-made damage (fired), salt-alkali corrosion, etc. The comprehensive assessment of diseases is 
mostly moderate and severe, and a small amount is endangered; the underground parts are mainly saturated with decayed, cracks, and warped, microbial damage, etc.

Combined with the results of the preliminary engineering geological survey, the site was excavated and sampled in situ. It was found that: the soil layer of the ruins is evenly distributed within 6 meters downward, and the sand layer with well-graded and large porosity is conducive to water evaporation. The groundwater depth is 5.2 meters, and the capillary water zone is about 1.2 meters high, as shown in Figure 5, it has been fully excavated to the bottom of the ruins of wooden bridge piles, the depth of the wooden piles is 4.9 meters, the volumetric water content of the sand in which the piles are located is $0.6-4.5 \%$. Among them, the soil moisture content is significantly lower than that of wooden piles, the result confirmed that the wooden bridge

piles were selected as the more convenient transport and water migration channels, and further indicate that the causes was mainly caused by groundwater migration. On the other hand, the water content of wooden bridge piles varies with the depth of the pile body. The surface volume water content of the above-ground part is $3-8 \%$, which is dry, and the underground part is mostly sub-saturated, and the surface volume water content is $8-29 \%$ (tested during field excavation), the overall moisture content change law is:

pith $\rightarrow$ heartwood $\rightarrow$ sapwood moisture content gradually decreases, and the moisture content of wooden bridge piles also shows a regular decrease from bottom to top, especially the water content is higher in the depth range of 1-2 meters underground.

\subsection{Wood Species of the Ancient Wooden Bridge Piles}

After the process of freezing, slicing, dyeing, dehydrating, and adding glue, it is sealed on a glass slide. Then we can observe, analyze and identify it under the microscope. The anatomical characteristics of the wood are shown in the figure 6. The identification results are as follows: the species of ancient bridge piles are identified as phoebe, fir, camphor, cypress, pine and other wood species, of which phoebe and larch are the majority. Both machilus and pine have good corrosion resistance and stable compression performance, are not easy to be eaten by insects, and the wood is light and not easily deformed, it is an ideal wooden building material.

As shown in the above, the Machilus sp. has the obvious growth rings, and it is the diffuse porous wood. The cross-section of the tube is round and oval. It has the single-tube hole and 2-3 radial-row multiple-tube holes. The tube holes are occasionally grouped with intrusions; single perforation, sparse perforation ladder-like. The pits between the tubes are arranged in a polygonal shape. The amount of axial parenchyma is small, ringshaped, sparsely shaped like a ring-tube bundle, and scattered, with a large number of oil cells or mucous cells. The wood fiber has a thin wall and a large number of marginal holes. There are very few wood rays in single row, multi-row rays are 2-3 cells wide and most are 10-20 cells high. It has the ray tissue abnormalities type $\nabla$ and $\varangle$; oil cells and mucous cells are few. The pitting type between the ray and the tube is the pitting type between the nicked and kidney-shaped, large round or tube-like pitting.

Larch sp. has the obvious growth rings, and it is the diffuse porous wood. The cross-section of the tube is round and oval. It has the single-tube hole and 2-3 radial-row multiple-tube holes. The tube holes are occasionally grouped with intrusions; single perforation, sparse perforation ladder-like. The pits between the tubes are arranged in a polygonal shape. The amount of axial parenchyma is small, ring-shaped, sparsely shaped like a ring-tube bundle, and scattered, with a large number of oil cells or mucous cells. The wood fiber 
has a thin wall and a large number of marginal holes. There are very few wood rays in single row, multi-row

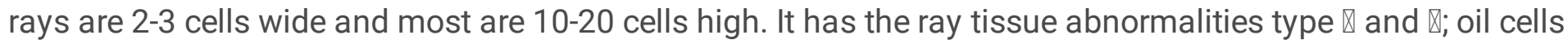
and mucous cells are few. The pitting type between the ray and the tube is the pitting type between the nicked and kidney-shaped, large round or tube-like pitting.

\subsection{Fungal Isolation, Identification and Screening of the Ancient Wooden Bridge Piles}

Since the site was under the simple preservation condition by the temporary protection greenhouses, the seasonal and daily temperature and humidity were changed greatly contribute to the growth environment of wood decay. The ancient bridge piles exposed caused the fungus to rapidly spread and grow on .The groundwater environment accelerates the development of the disease. As shown in Fig.7, the six samples collected were classified into 127 species, among which the microbial species richness of the samples in the area where the ancient bridge pile and the soil contact was relatively high. According to species classification, most of them are determined as follows: wood saprotroph囚endophyte冈ectomycorrhizal and animal endosybiont. Ascomycetes species had the highest content in the samples and basidiomycetes were the second.

\subsection{Biological Invasion of the Ancient Wooden Bridge Piles}

As shown in the above Fig.8, the structure of the ancient wood pile is loose and seriously rotten, residual organisms, microbial erosion, plant roots tillering, organism parasite eggs, and organism excrement were serious observed. In particular, the piles were penetrated by new plants and destroyed by root system. At the same time, plants and their root systems were not found in a large area of soil within the site, which indicated that the ancient bridge pile was a channel more conducive to groundwater evaporation, storage and transport, and the pile provided water for the epiphytic plants. Therefore, the damage of plant roots in this site is also worthy of attention, which requires biological management.

\subsection{Causes for Deterioration}

The preservation status of the Shahe ancient bridge site is worrying. It is not difficult to see that the influence of groundwater environment on the site cannot be ignored: On the one hand, due to the climatic characteristics of groundwater evaporation at the site, the alternation of dry and wet and the soluble salt carried in the process of groundwater evaporation have significantly accelerated the deterioration of the ancient site and its cultural relics; on the other hand, the erosion and destruction of the site caused by microorganisms, organisms, and plants that depend on water and humidity and the ecological environment around the site is also worthy of attention. If the groundwater environment is not treated as soon as possible and left unchecked, these wooden piles that have been preserved for thousands of years will eventually be destroyed by microorganisms, organisms, and plants. Therefore, the groundwater management has become the primary problem facing the protection of ancient sites today.

\section{Conclusion}

With the improvement of the requirements and concepts for the protection of ruins, we will find that the ruins with its environment is an inalienable and closely linked ecosystem, and it is independent and interacting with 
each other. How to know and understand its existence, and how to verify the various causes of the disease and its conditions or factors that prompted it to continue to develop? How to accurately evaluate its status and predict the speed and hazards of continuous development?

The diseases in ancient ruins are mostly influenced by geological, hydrological and environmental factors. Therefore, for the protection of cultural ruins, it is necessary to find a breakthrough in the correlation between the environment in which they exist and the causes of their diseases. At the same time, the aim is to control or completely control the factors that cause site destruction or accelerate site degradation. According to the data analysis of geotechnical investigation, it is found that the hazards of the Shahe Ancient Bridge Site and its wooden bridge piles mainly caused by groundwater.

In general, the most important goal of site protection is to control or restrain a certain type or several factors in order to stop or delay the destruction of sites caused by these factors, and these measures were visible and effective in the short term. However, from the perspective of the self-regulation and rebalancing of the site ecosystem, it would be that "effective action at the moment" has disturbed the balance of the ecosystem and will accelerate the deterioration of the site. In a practical sense, the effective management and protection of sites should balance various factors or establish a more stable balance, gradually reduce its threat, and finally realize the long-term preservation and survival of precious cultural heritage. The author believes that although the most effective way to protect the ruins is to improve the methods and technologies, the protection concept and the cognition of the ruin ecosystem determine its destiny. The geochemical characterisation and monitoring data will also be used to predict the effects of various types of perturbation on longer preservation and proposed feasible and applicable for a long time countermeasures in preservation studies.

\section{Declarations}

\section{Acknowledgement}

The authors gratefully acknowledge the financial support by the National Natural Science Foundation of China (No. 41601232) and the approval and financial support of the State Administration of Cultural Heritage for the Shahe Ancient Bridge Site Protection and Renovation Project (Cultural Relic Protection Letter[2018] 1135).

The authors would like to thank the Jingzhou Preservation Center of Cultural Relics and Shahe Ancient Bridge Site Cultural Relics Administration for their support and research cooperation, and also thanks to the Tang Hanguang Gate Museum for sharing its monitoring and protecting experience in the ruins.

\section{Conflict of interest}

The authors declared that they have no conflicts of interest to this work. We declare that we do not have any commercial or associative interest that represents a conflict of interest in connection with this work submitted.

\section{References}


[1] F. Casarin, C. Modena, Seismic assessment of complex historical buildings: application to Reggio Emilia Cathedral, Italy, Int. J. Archit. Herit. 2(3) (2008) 304-327. https://doi.org/10.1080/15583050802063659

[2] G. Chellini, L. Nardini, B. Pucci, W. Salvatore, R. Tognaccini, Evaluation of seismic vulnerability of Santa Maria del Mar in Barcelona by an integrated approach based on terrestrial laser scanner and finite element modelling, Int. J. Archit. Herit. 8 (6) (2014) 795-819. https://doi.org/10.1080/15583058.2012.747115

[3] G. De Matteis, F. M. Mazzolani, The Fossanova Church: seismic vulnerability assessment by numeric and physical testing, Int. J. Archit. Herit. 4 (3) (2010) 222-245. https://doi.org/10.1080/15583050903078903

[4] G. Barbieri, M. Valente, L. Biolzi, C. Togliani, L. Fregonese, G. Stanga, An insight in the late Baroque architecture: an in tegrated approach for a unique Bibiena church, J. Cult. Herit. 23(1) (2017) 58-67. https://doi.org/10.1016/j.culher.2016.07.006

[5] R. Giannini, T. Pagnoni, P.E. Pinto, I. Vanzi, Risk analysis of a medieval tower before and after strengthening, Struct. Saf. 18 (2-3) (1996) 81-100. https://doi.org/10.1016/0167-4730(96)00007-0

[6] B. Valentino, P. Marco,Alessandra M., Experimental cyclic and dynamic in-plane rocking response of a masonry transverse arch typical of historical churches, Eng. Struct. 147 (2017) 285-296. https://doi.org/10.1016/j.engstruct.2017.05.058

[7] S. Casolo, G. Milani, G. Uva, C. Alessandri, Comparative seismic vulnerability analysis on ten masonry towers in the coastal Po Valley in Italy, Eng. Struct. 49(1) (2013) 465-490.

https://doi.org/10.1016/j.engstruct.2012.11.033

[8] M. Pieraccini, D. Dei, M. Betti, G. Bartoli, G. Tucci, N. Guardini, Dynamic identification of historic masonry towers through an expeditious and no-contactapproach: application to the 'Torre del Mangia'in Siena (Italy), J. Cult. Herit. 15(3) (2014) 275-282. http://dx.doi.org/10.1016/j.engstruct.2017.05.058

[9] G. Fortunato, M.F. Funari, P. Lonetti, Survey and seismic vulnerability assessment of the Baptistery of San Giovanni in Tumba (Italy), J. Cult. Herit. 26 (1)(2017) 64-78. https://doi.org/10.1016/j.culher.2017.01.010

[10] L. Berto, A. Doria, P. Faccio, A. Saetta, D. Talledo, Vulnerability analysis of built cultural heritage: a multidisciplinary approach for studying the Palladio's Tempietto Barbaro, J. Archit. Herit. 11 (6) (2017) 773790. https://doi.org/10.1080/15583058.2017.1290853

[11] V. Bosiljkov, M. Uranjek, R. Zarni, V. Bokan-Bosiljkov, An integrated diagnostic approach for the assessment of historic masonry structures, J. Cult. Herit. 11(3) (2010) 239-249. https://doi.org/10.1016/j.culher.2009.11.007

[12] V. Greif, J. Vlcko, Key block theory application for rock slope stability analysis in the foundations of medieval castles in Slovakia, J. Cult. Herit. 14 (4) (2013) 359-364.

https://doi.org/10.1016/j.culher.2012.09.001

[13] R. Aguilar, R. Marques, K. Sovero, C. Martel, F. Trujillano, R. Boroschek, Investigations on the structural behaviour of archaeological heritage in Peru: from survey to seismic assessment, Eng. Struct. 95 (1) (2015) 
[14] Zhongtang Yang: "Study on the Sediments of the Shahe Ancient Riverbed in Xianyang City, ShaanxiTalking about the Location of the West Wei Bridge", "Northwest Geology" Issue 2, 1993. https://kns.cnki.net/kcms/detail/detail.aspx?FileName=XBDI199302004\&DbName=CJFQ1993

[15] Liang Yun, You Fuxiang, Guo Feng: "The New Discovery of the Three Bridges on the Han and Weihe Rivers", "Journal of the National Museum of China", Issue 4, 2013.

https://kns.cnki.net/kcms/detail/detail.aspx?FileName=ZLBK201304002\&DbName=CJFQ2013

\section{Figures}

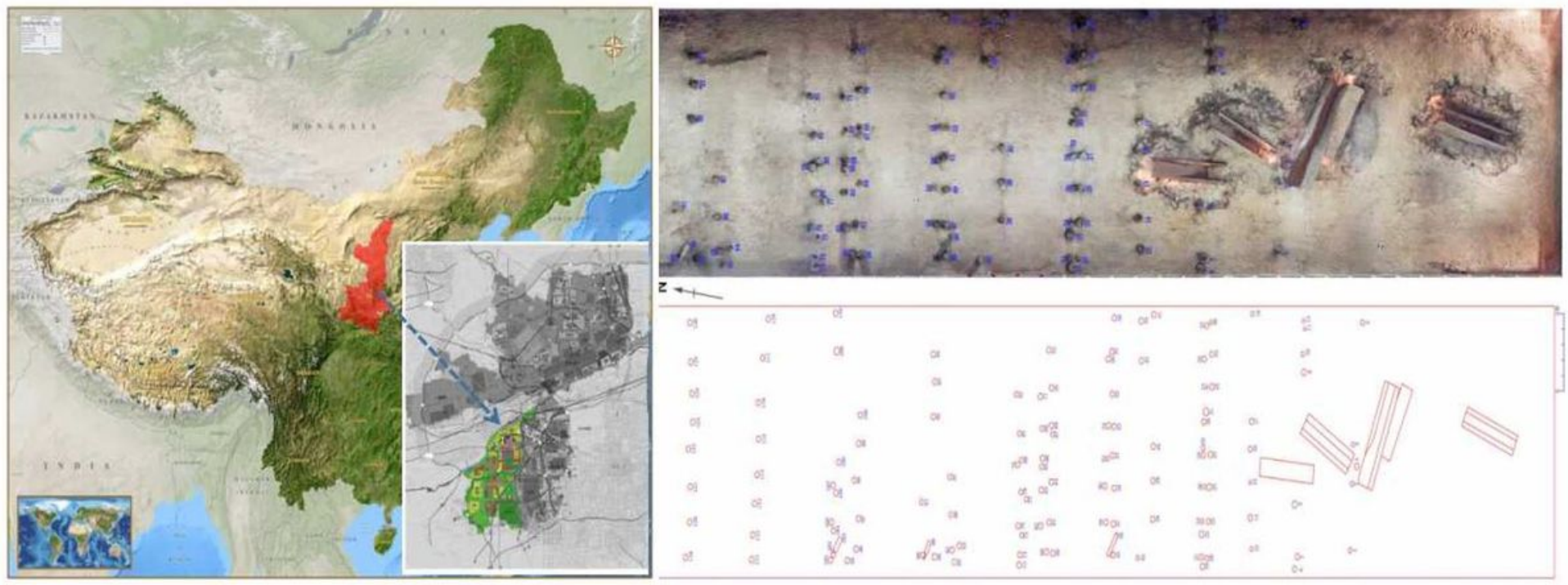

\section{Figure 1}

Location map showing the ruins. Note: The designations employed and the presentation of the material on this map do not imply the expression of any opinion whatsoever on the part of Research Square concerning the legal status of any country, territory, city or area or of its authorities, or concerning the delimitation of its frontiers or boundaries. This map has been provided by the authors. 

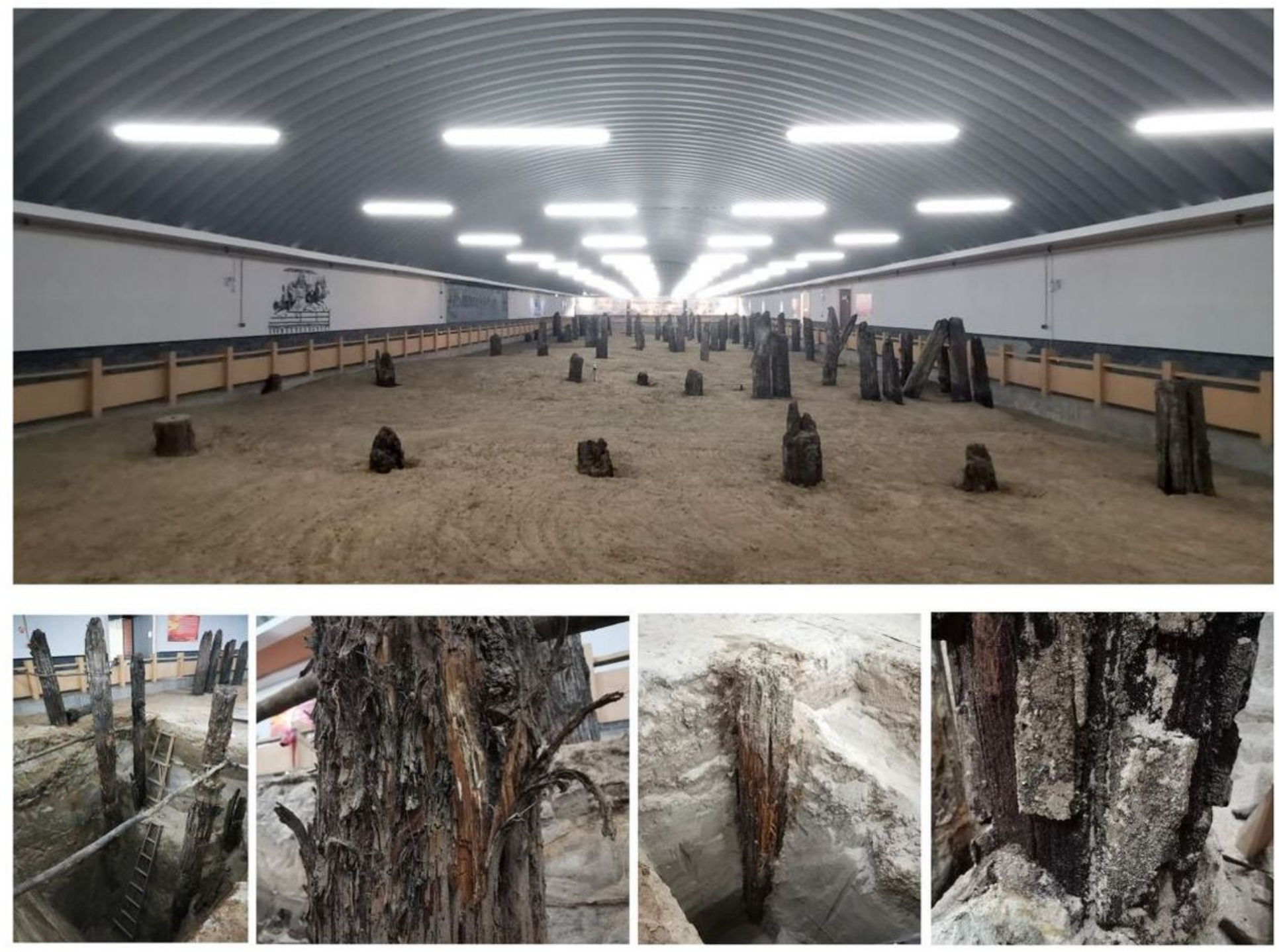

Figure 2

Views of the ruins 


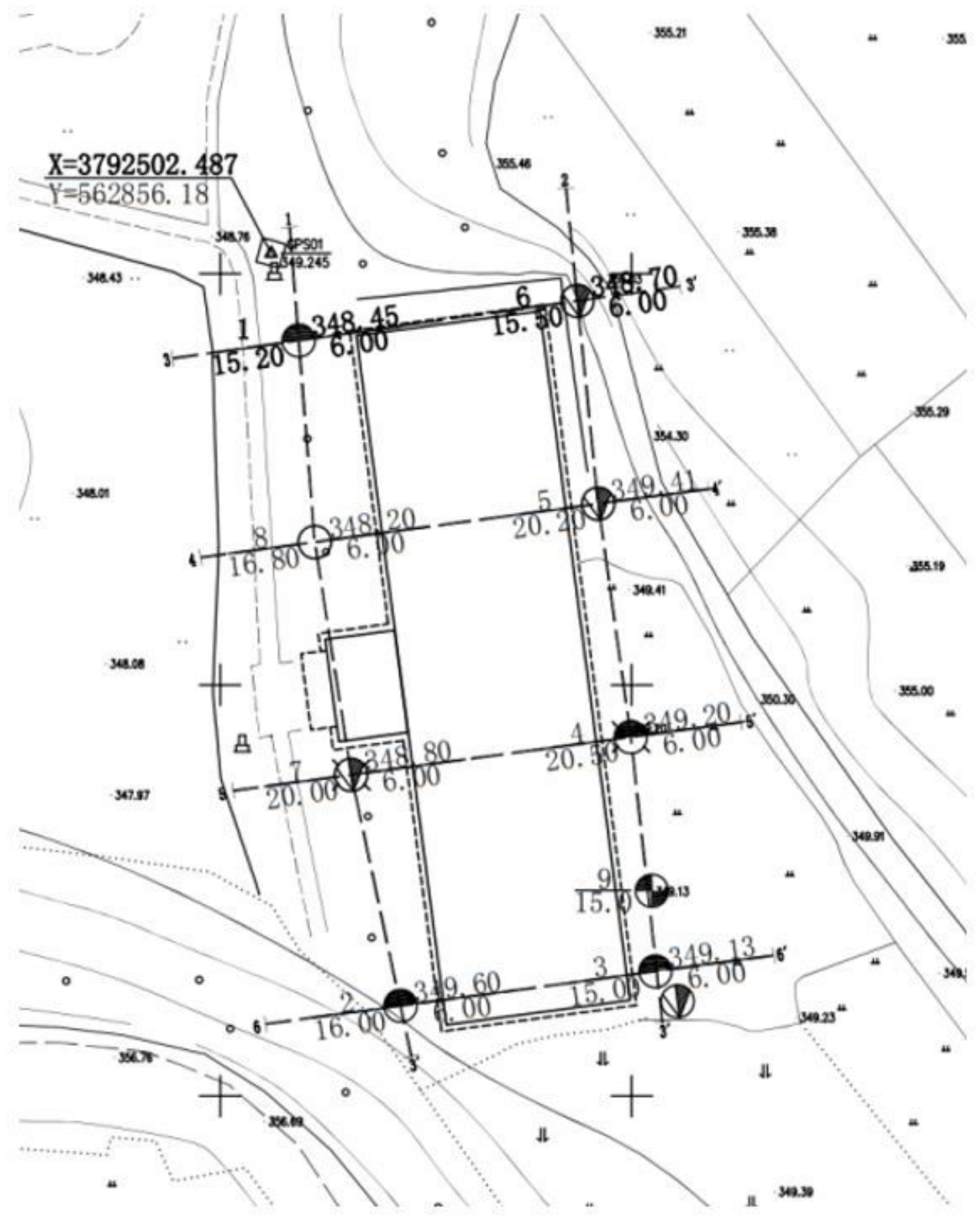

Figure 3

Map showing the location of borehole in the ruin. Note: The designations employed and the presentation of the material on this map do not imply the expression of any opinion whatsoever on the part of Research Square concerning the legal status of any country, territory, city or area or of its authorities, or concerning the delimitation of its frontiers or boundaries. This map has been provided by the authors. 
Elevation

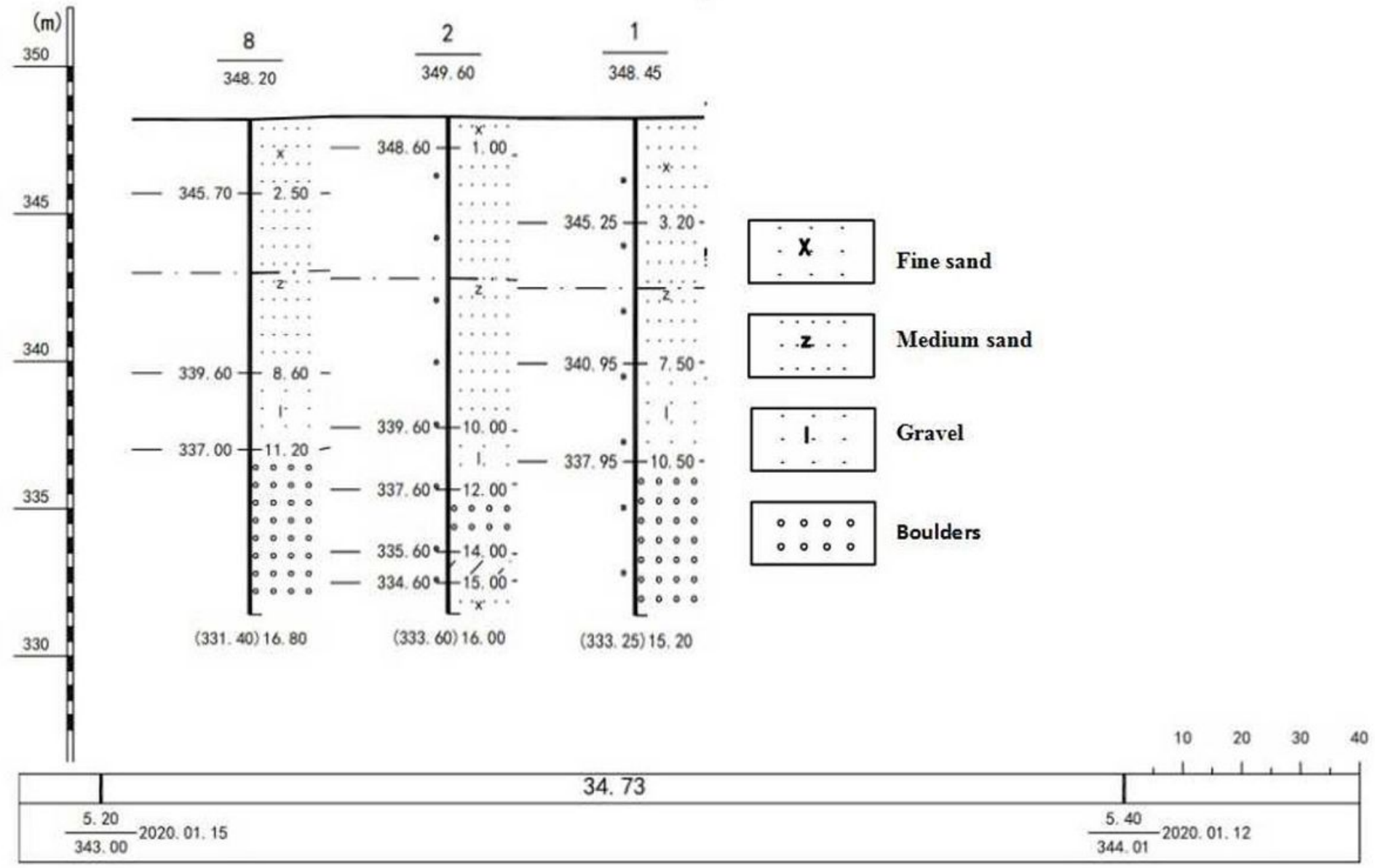

Figure 4

Simplified geological stratigraphy observed in borehole $\mathbb{1 , 2 , 8 \rrbracket}$ 


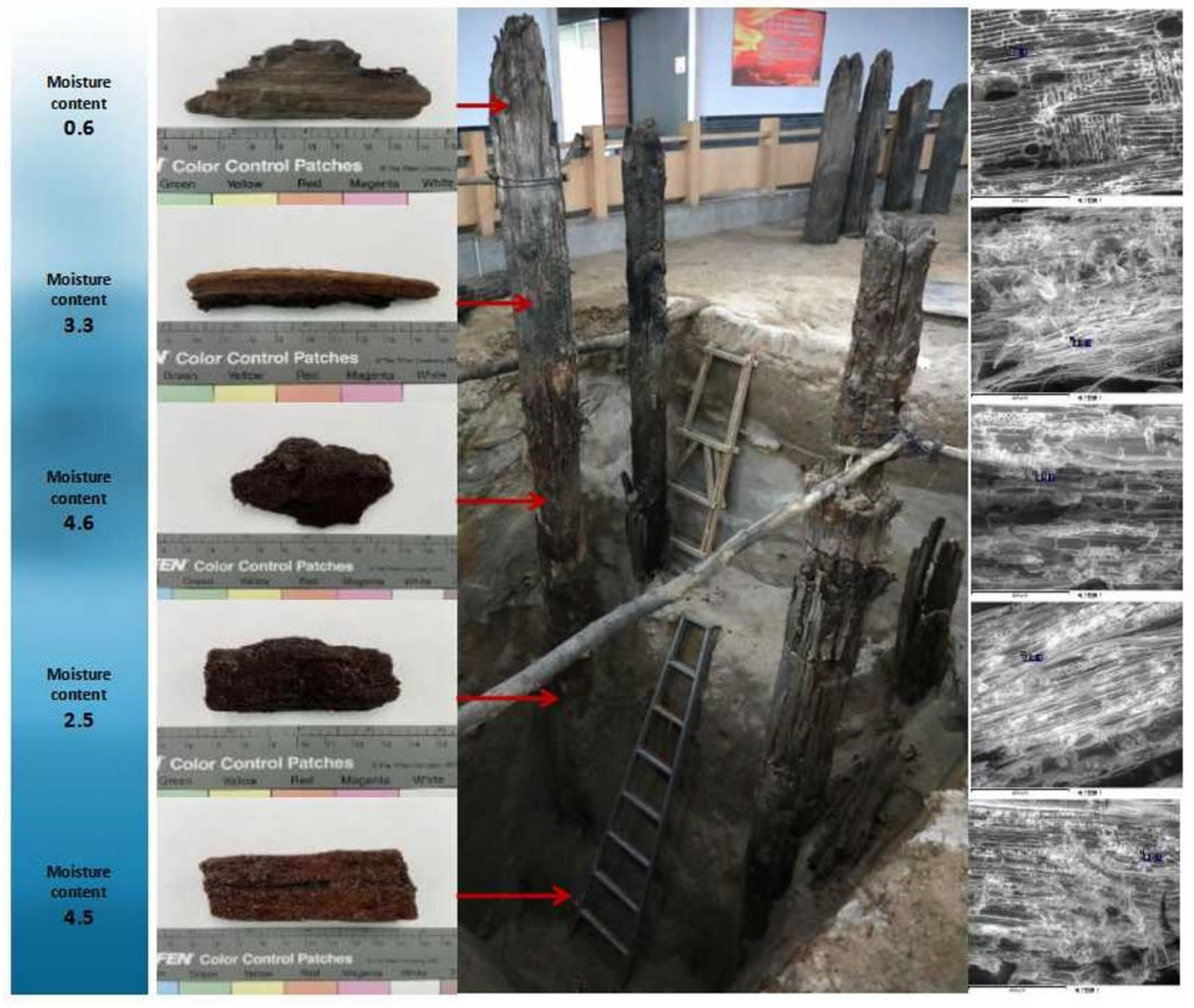

\section{Figure 5}

Soil profile of the excavation site $\$ moisture content of the soil (left1), photographs (left2) and microstructure (right) of wood sample with different buried depths 


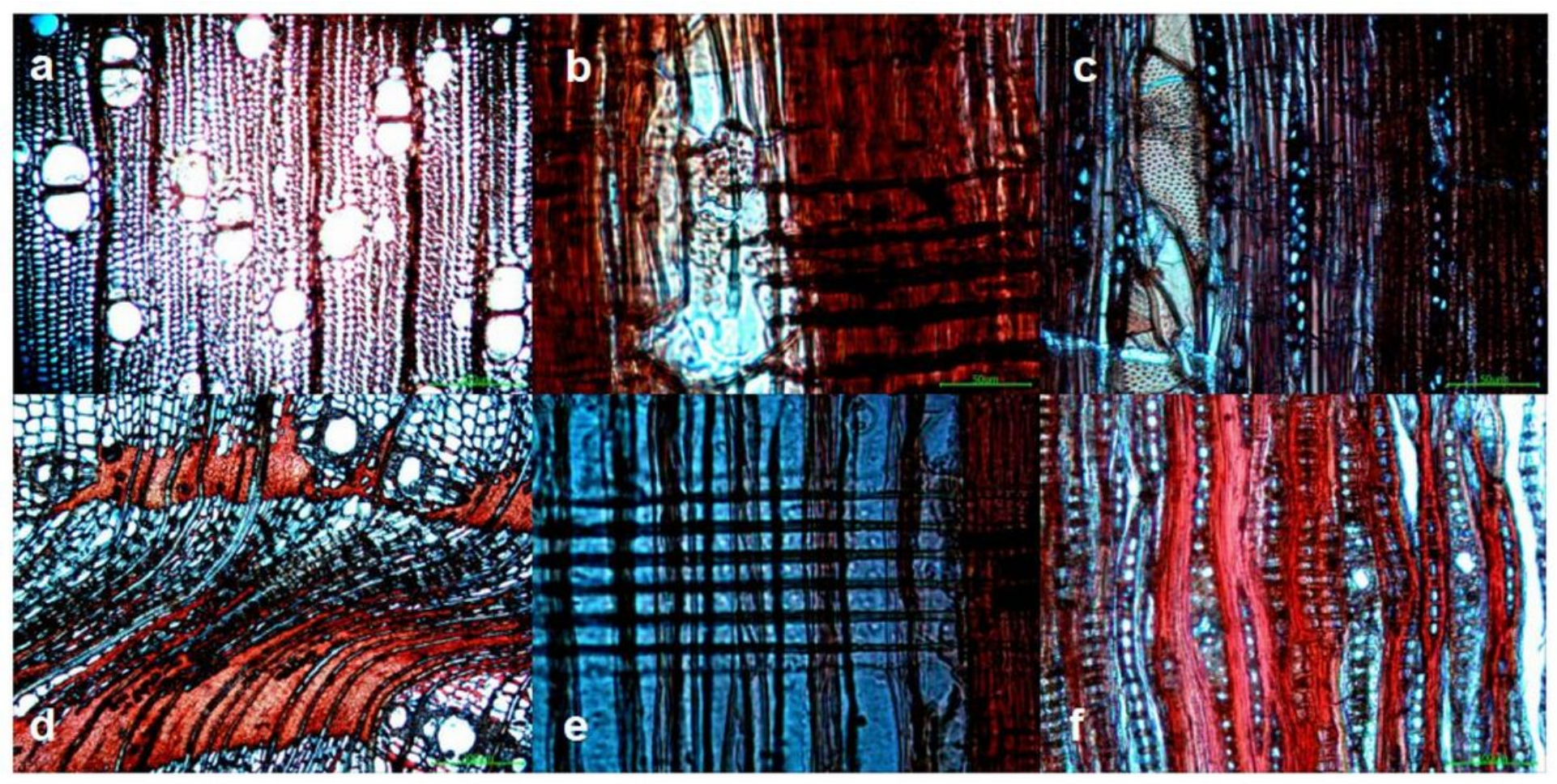

Figure 6

The anatomical characteristics of the wood of the machilus (a-cross section, b-diameter section, c- chord

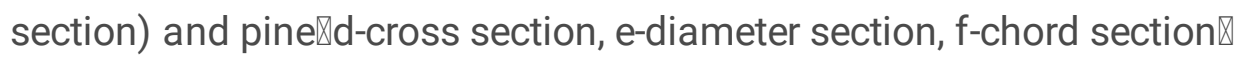

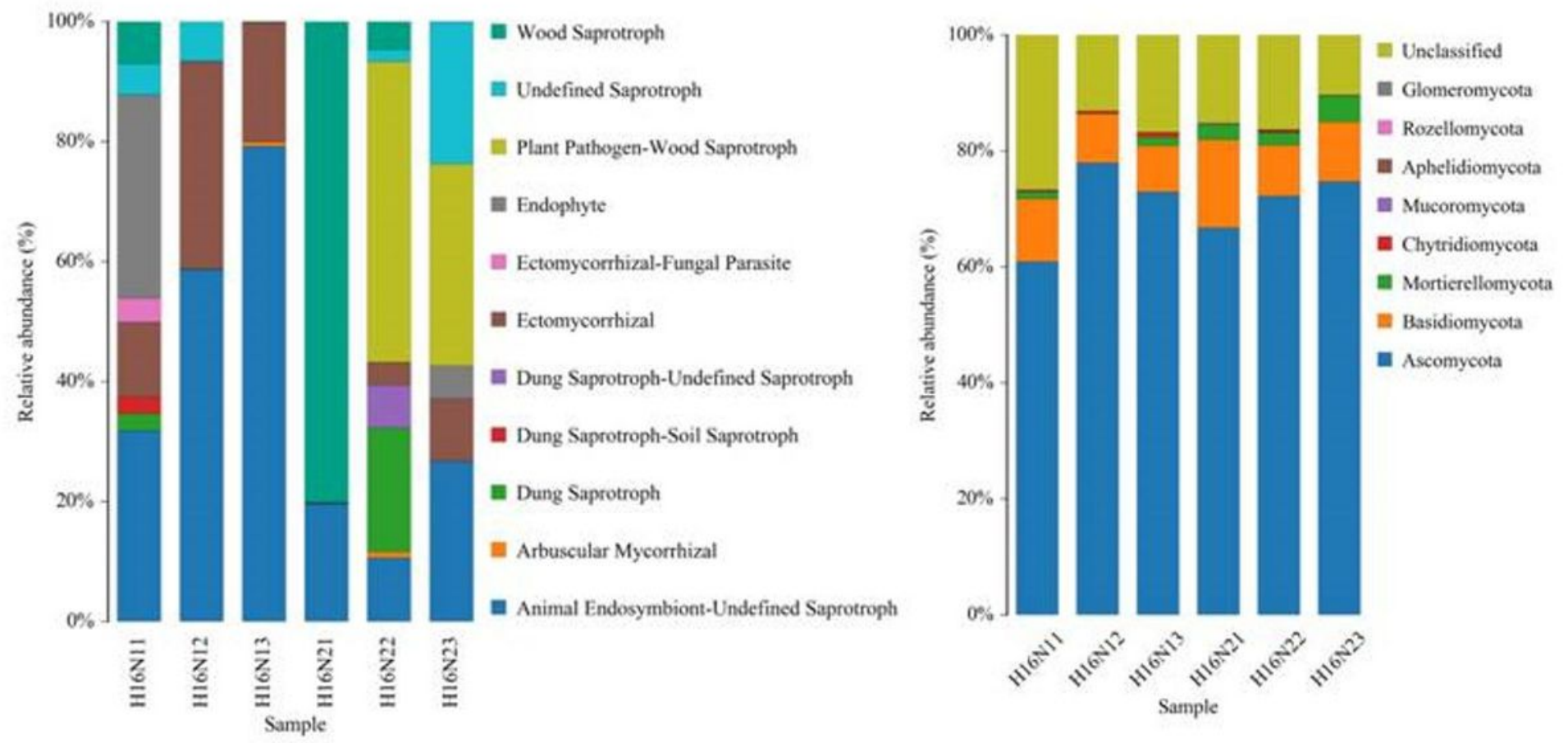

Figure 7

Fungal abundance in different samples 


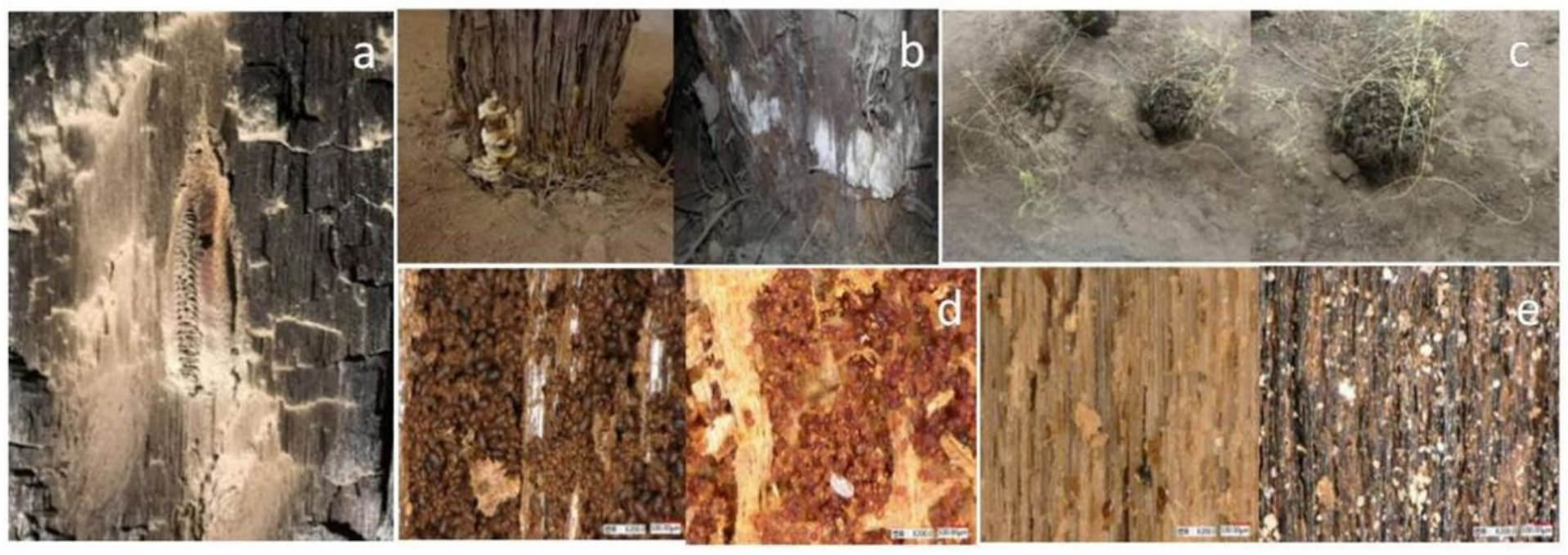

\section{Figure 8}

Visual observations of the microbial, biological, and plant erosion (a. Residual organisms, b. Microbial erosion, c. Plant roots tillering, d. Organism parasite eggs, e. Organism excrement)

\section{Supplementary Files}

This is a list of supplementary files associated with this preprint. Click to download.

- ResearchHighlights.docx 